\title{
DIMENSIONS OF ELECTORAL REFORMS IN NIGERIA
}

\section{Emmanuel Olugbade 0jo ${ }^{1}$}

\section{Introduction}

One of the fundamental problems that post-colonial African states, including Nigeria, are faced with is how to best sustain and eventually consolidate democracy - in this case one-man-one-vote - through credible elections (Kolawole 2007, I5). No doubt, this simple task has become a herculean one in the whole continent of Africa, few states could lay claim to having genuinely conducted free and fair elections as universally perceived. The tendency in many instances is to substitute a bastardised variant of it and justify its efficacy on the platform of expediency to merely secure governmental legitimacy (Iwu 2008, 37). One country that perfectly represents such negativity which serves our immediate purpose here is Zimbabwe (Vale 2005 , I4). This is a country where a one-time freedom fighter gained power and refused to dispense with it even after years of exercising it and in spite of the natural law of diminishing returns, which daily affected his capability to provide real governance. It was simply a case of a liberator turned oppressor (Femi 2007, II). The picture did not change until Robert Mugabe, who was winning all elections, was removed in old age by military putsch before his eventual demise.

In Nigeria, which is the focus of this study, it has been pretty difficult for elected presidents to tinker with the constitutionally established tenure of maximum of two terms (of eight years) even when they desire an extension of tenure like former President Olusegun Obasanjo tacitly attempted (I9992007). However, successive elections are hardly free and fair. The imperatives of electoral reforms in Nigeria can be summed up thus:

I Department of Political Science, University of Ilorin. Ilorin, Nigeria. E-mail: eojor2000@ yahoo.com. ORCID: https://orcid.org/0000-0003-4430-6354 
Nigeria has a history of violent and deeply flawed elections. At least 300 people were killed in violence linked to the last general election in 2007 [...] since November 2010, more than 50 people have been killed in violence linked to political party primaries and election campaigns and the level of violence is expected to increase in the run-up to the April poll (see Joint statement by Global Watchdog and the Nigeria Bar Association NBA in 20II, The Nation, I4 March, 20II, 4).

In a perceptive work, Adekanye (I990, 2) summed up the problem thus: "elections in the country have often been characterized with political tension, crisis, assassination and high levels of violence".

The sad reality in Nigeria, Africa's largest democracy, is not unconnected with her capacity and political will to conduct free, fair and peaceful elections. Since independence in I960, "violence and myriad irregularities have persistently marred the process of electing the country's leaders" (Onwudiwe and Berwind-Dart 2010, 2). The snag is that fierce ambition among Nigerian politicians is certainly part of the problem. In addition, "elections have been about power: controlling it, undermining it, and distributing it" (Samuel 20I6). In a country that is not only plural but deeply divided yearning for national integration in all ramifications.

In view of the foregoing, the thrust of this paper is basically to justify the imperatives of electoral reforms cum their dimensions in Nigeria. The paper is organized into a number of sections. With the above introductory remarks, the paper proceeds to an exploration of democracy and elections, bringing out the nexus. Part three of the paper is a review of conduct of general elections in Nigeria between I999 when the nascent democracy was inaugurated till the 20I9 recently conducted elections. Part four dwells on the real focus of the paper, which is the various dimensions electoral reforms should take in the interest of the polity so that the system may not suffer another reversal to dictatorship and autocracy.

\section{Democracy and elections: a nexus}

In the extant literature on democratic consolidation, generally elections and democracy are interwoven. The psychology of the elective process lies in the fact that it gives the citizenry a sense of relevance. It imbues him with the fulfilling sense of participation and partaking in public policy through his elected representatives. Put differently, the linkage between elections and democracy is clear, so far, no other method for selecting the 
leadership of a democratically ruled society, has been proved or shown to be superior (Ogunsanwo 2003, II). Thus, a great deal of emphasis has been placed on holding regular elections and this has often led to the misconception that they are an end in themselves and not a means to an end. It is generally agreed that elections are a hallmark of democracy and an important instrument through which leaders are elected to public office. Nevertheless, we recognize that the mere existence of political parties and the holding of regular elections, although important ingredients of democracy, do not in themselves amount to democracy. They remain, however, central pillars of its institutionalization and consolidation; without them, democracy cannot exist. In theory, elections are perceived to enhance democratic governance but in practice some elections are merely a charade geared to legitimating authoritarian rule (Molomo 2006, 23-24; Ojo 2006, 105-123).

As it were, elections broadly conceived, refer to the process of elite selection by the mass of the population in any given political system. Beyond the role of elite recruitment, there is a kind of general acceptance that elections are means by which popular commitment to the regime may be mobilized (Anifowose 2003, 2I). In a more explicit manner, the core functions of elections can be summarized as follows:

- recruiting politicians and public decision-makers;

- making governments;

- providing representation;

- influencing policy decisions;

- educating voters;

- building legitimacy;

- strengthening elites;

- providing succession in leadership;

- extension of participation to many people (Anifowose 2003, 2I).

However, for an election to perform democratic utility function in a polity, such polity must, as a matter of necessity, allow the media to have power to decide how news is to be covered, who is to be invited to comment, and who is not to be invited (Olurode I990, 3). Put differently, press freedom is a sine qua non to a free and fair election and by extension democratic sustenance and consolidation (Ojo 2003; 2007b, 72-86). 
In essence, a vote is democratic if its procedure is democratic. The procedure is democratic if all the following conditions or substantial parts of them are met:

(a) Every preference is freely revealed i.e. the process is free.

(b) There is a level (competitive) playing field for all contesting candidates and their parties.

(c) Every valid vote counts.

(d) There is no single vote whose preference automatically determines a majority i.e. there is no autocracy.

(e) No "proxy" votes are allowed.

Fraud in the process of aggregation is often systematically organized and its enormity has clear correlates to wit:

(a) The greater the degree of power centralization, the greater is the possibility of vote rigging that may occur.

(b) The bigger the size of government, the more the variety of vote rigging.

(c) The lower the degree of accountability of governments/representatives, the higher the level of corruption.

(d) In an environment of poverty, votes, which are a democratic resource bound by decision-role, may acquire market value, determined by competition among the rich who wish to acquire power in addition to wealth. So poverty may entrench a (corrupt) plutocracy (Olurode and Anifowose 2004, vii; Ojo 2006, I05I23).

Nonetheless, elections should enable a democratic society to translate the preferences of its citizens into wise policies. In reality, however, elections do not always produce such results. As observed in Magstadt and Schotten (Anifowose 2003, 40), among the inherent limitations of elections as vehicles of public choice are the following:

(a) Candidates may find that they cannot carry out their promises once elected to office - certain pledges may prove impossible to implement either because candidates deliberately overstated what could be accomplished or because they simply underestimated the forces of resistance. 
(b) If public opinion, one the most important issues of the day, is ill-defined; badly divided newly elected officials may receive no clear mandate from the voters. And even if such a mandate is given, an elected official may regard public opinion on a particular issue to be misguided and either ignores it or tries to change it.

(c) After being elected to office, a candidate may simply have a change of heart about the desirability or feasibility of a particular policy. The influence of new interest groups, exposure to more and better information, and the realization of the intricate relationship between various domestic and foreign policies can all have a profound impact on a newly elected official.

To extend our typology of the nexus between elections and democracy further may not serve any useful purpose, most especially in a situation whereby scholars of "stasiology" have failed to reach a consensus (Ojo 2007, 4-I3I). We now move to a brief review of elections in the Fourth Republic.

\section{Dimensions of electoral reforms}

The 2007 flawed election, which has been attested to by diverse stakeholders both local and international, has really necessitated the intense call for the restructuring of the electoral system (Pham 2007, 53). But it needs to be emphasized that Nigeria has attempted electoral reforms in the past, but usually under the military whose true motive was to claim some dubious reforming mission so as to try to justify its illegal seizure of power. And that is why nothing has really changed. Behind the façade of this reform effort was a calculated desire never to see them succeed so that they could continue to hold on desperately to power. The last of such panels was the Justice Babalakin Commission of Enquiry into the affairs of Federal Electoral Commission, FEDECO in I986 (Tinubu 2007, 8).

In spite of many useful and informative memorandum submitted to the panel, there had been no government white paper on the recommendations. And because of this bad faith, the so-called reforms of the late eighties and early nineties for instance, crashed and burned, ending with the perverse annulment of the June I2, I993 election adjudged to be the most free and fair election the nation ever witnessed ${ }^{2}$. And thereafter, things just

2 See The Punch, $\mathrm{I}^{\text {th }}$ June, 2008. 
got worse and worse culminating in what has been generally believed as the most flawed and compromised national "election" in Nigeria's history, under the self-interested watch of a militocrat — that is, "soldier-turned born-again" politician - Chief Olusegun Obasanjo (Tinubu 2007, 8). With that existential reality of Nigerian polity, the beneficiary of the discredited 2007 polls - President Umaru Musa Yar-Adua - on assumption of office acknowledged the perverted nature of the country's electoral system which has however warranted his inauguration of a 22-member "maggie" to recommend far reaching reform agenda ${ }^{3}$.

For record purposes, the Terms of Reference (ToR) of the Electoral Reform Committee is as highlighted hereunder:

i. undertake a review of Nigeria's history with general elections and identify factors which affect the quality and credibility of the elections and their impact on the democratic process;

ii. examine relevant provisions of the 1999 Constitution, the Electoral Act, and other legislation that have bearing on the electoral process and assess their impact on the quality and credibility of general elections;

iii. examine the roles of institutions, agencies and stakeholders in shaping and impacting on the quality and credibility of the electoral process. These should include Government, Electoral Commissions, Security Agencies, Political Parties, and Non-Governmental International Community;

iv. examine electoral systems relevant to Nigeria's experience and identify best practices that would impact positively on the quality and credibility of the Nation's electoral process;

v. make general and specific recommendations (including but not limited to constitutional and legislative provisions and/or amendments), to ensure:

a. a truly Independent Electoral Commission imbued with administrative and financial autonomy;

\footnotetext{
3 The names of the 22-man Electoral Reform Committee inaugurated on 29 August 2007 are: Mohammadu Lawal Uwais - Chairman and a former Chief Justice; Godwin Ononiba; Olisa Agbakoba; Okon Uya; Ahmadu Kurfi; Musiliu Smith; Bolaji Akinyemi; Gambo Balarade Abdullahi; Grace Alele-Williams; Toyin Olakunmi; Jibril Ibrahim; Oladayo Popoola; Ahmed Lemu; Attahiru Jega; Ndamusa Alao; John E. Odah; Abduraheem Ujo, 'Dije Bala; Aliyu Umar; Steven Dike; Festus Okoye; Hassan Kukar. For information on the background of each member of the Committee, which has a year to complete its assignment, see The Nation, (Lagos), 23 August, 2007, pp. I\&2.
} 
b. an electoral process that would enable the conduct of elections to meet acceptable international standards;

c. legal processes that would ensure that election disputes are concluded before inauguration of newly elected officials; and

d. mechanisms to reduce post-election tensions including possibility of introducing the concept of proportional representation in the constitution of governments.

vi. make any other recommendations deemed necessary by the Committee.

We now proceed to the critical areas where the reform agenda can be carried out in the interest of the polity. We begin with the Independent National Electoral Commission (INEC), constitutionally charged with the responsibility of administration of elections in Nigeria.

\section{Independent National Electoral Commission (INEC)}

In a national wide opinion survey by IFES-Nigeria (2007), most especially in the wake of the elections ${ }^{4}$, election observers called into question INEC's independence and impartiality. The survey results show that these doubts are shared by many in the public when asked to choose between two opposing statements - whether INEC is a neutral body guided in its work only by the law or whether INEC makes decision that favour particular people or interest - a slim majority select the statement that INEC is biased (53\%), while four in ten $(40 \%)$ lean more towards the description of INEC as a neutral body. Not surprisingly, nearly all of those who have little or no confidence in INEC incumbida (93\%) vs. (31\%). However, even many of those who express confidence in INEC, doubt its independence. Nearly a third (3I\%) of those who say they have at least moderate confidence in INEC also

\footnotetext{
4 See An Election Programme to Fail: Preliminary Report on the Presidential and National Assembly Elections held on Saturday, April 2I, 2007 (2007 April). Retrieved July 23, 2007 from http://www.american.edu/ia/idem/nigeria/reort_07042I.pdf. The results of this survey are based on face-to-face interviews conducted under the direction of IFES in Practical Sampling International. The interviews were with 2,410 Nigerians I8 years of age or older and were conducted between February I3 and 25, 2007. Interviews were conducted in all 36 Nigerian states and the Federal Capital Territory and are representative of the Nigerian adult population. The survey was paid for by the Department for International Development (DFID) under IFES "Nigerian Election Support 2007" Program. See, IFES Monograph "What Nigerians Think: Nigerian Public Opinion in the Pre-Election Environment, April 2007, IFES - Nigeria, Abuja.
} 
say INEC favours particular people or interests. With an empirical finding', demonstrating evidence that there is low confidence in INEC, any meaningful electoral restructuring should begin with the election administrator - INEC.

The fundamental problem with INEC, which makes it potential targets of restructuring and reform, is basically constitutional. No doubt, any electoral administrator like INEC that will perform creditably must be independent, impartial, transparent and indeed accountable. But the kind of constitutional hindrances on the way of INEC is daunting. For instance, Section 156 (i) (a) of the 1999 constitution (as amended) provides that those to be appointed as Electoral Commissioners must be qualified to be members of the House of Representatives. The interpretation of this which may not actually be in the spirit and letter of the constitution, is that those appointed as members of the electoral commission should be party members, as party membership is a major criteria to be elected into the House of Representatives in Nigeria (Adejumobi 2007). Not only that, section I4(2) 9; in the Third schedule, part one of the Federal Executive bodies in the Nigerian I999 constitution empowers the President of the Federal Republic of Nigeria to appoint Resident Electoral Commissioners for all the States (36) of the federation and the Federal Capital Territory (FCT), Abuja without recourse to the National Assembly for approval. No doubt, this provision has given any ruling party and most especially the incumbent President the leverage to appoint anyone who may be willing to do his biddings.

Connected also with the constitutional problem is the structural and institutional dimension to the electoral management. It is well known that INEC is far from being independent of the Executive organ of government. This is not unconnected with the fact that the chairman of INEC, and the 37 Resident Electoral Commissioners (RECs) were not only appointed by the President, they also report to him. In terms of financial autonomy too, the commission has a long way to go if it will ever be independent. For instance, for smooth operation of the commission, its financial 'fate' is at the mercy of the Federal Minister of Finance who is also appointed by the President. The Executive headed by Mr. President does not only determine the levels of funding and disbursement to the Commission, it also determines when and how the allocation to INEC is to be released. It is for this constitutional lacuna that the body performed woefully in the administration of 2007 general elections (Ijim-Agbor 2007, 79-94).

5 See An Election Programme to Fail: Preliminary Report on the Presidential and National Assembly Elections held on Saturday, April 2I, 2007 (2007 April), page 29. 
Therefore, INEC must be independent and be seen to be so legally, structurally, financially and in virtually all ramifications. The personnel who will lead the national electoral body and the national commissioners should be appointed in a manner that truly confers on them the garb of independence and more critically, independence of thought and action. To achieve this, appointments of Electoral Commissioners and their principal officers have to be rooted in a system which does not allow a sitting President or Governor to appoint electoral umpires that will supervise elections into which they are either participants or personally interested in (Tinubu 2007). Only under such a system will the people's confidence in the election process be restored.

In the same vein, the I999 constitution needs to be amended to grant INEC real autonomy. The legal backing may have to provide for INEC that is autonomous structurally and has financial autonomy not only administrative one. The arrangement should be akin to the judiciary's consolidated fund which cannot be tampered with by the executive arm of government.

Perhaps more critical is the imperative of deepening the deployment of technology in the management of the voters' register, voting and result collation processes. Though this should be done with caution; e-voting in a developing country like Nigeria could face a number of challenges which includes but not limited to hacking of voting machines, hacking of election campaign data, and hacking of online voting itself. Be that as it may, INEC needs to find a way of prosecuting electoral offenders. The electoral body should find a way to deal with a situation in which Returning Officers are compelled to declare winners under duress. Hence, it is a cheering news that INEC is proposing 34 amendments to the Electoral Act 2010 Amendment Bill.

\section{Political parties}

No doubt, political parties in all regions and climes of the world are important components of liberal democracy and electoral processes. Political parties produce the candidates, set the parameters of issues and agenda within which elections are to be fought and are further expected to perform these duties from one election to another (International IDEA 2000, 226227). The growth of modern democratic practice revolves around political parties, which stand out as organized platforms for the articulation of aspirations and canvassing for electoral votes. While the idea of independent candidacy is practiced in some democracies, it remains an exception to the rule of political organization or the machinery through which government is formed and power is acquired. 
Under the I999 Nigerian constitution, only duly registered political parties licensed by the Independent National Electoral Commission (INEC) can take part and present candidates for election into all the offices in the federation. In other words, any Nigerian seeking elective office must be a card-carrying member of such a party; independent candidature is not provided for in the constitution. Put differently, political parties are really imperative in Nigeria's nascent democracy. Expectedly, they tend to play a critical role in promoting democratic thinking and democratizing political systems. They are instruments linking the rulers to the ruled. Parties are thus basic organizational means by which people compete in elections for the rights to formulate and implement their policy objectives through the political system. Indeed, according to leading scholars of party politics, democracy is a function of competing and conflicting parties and that there is a structural link between mass mobilizing parties and political participation as it is the case in Europe (Manafu I998, I-26).

The snag however is that there is a missing link in Nigerian politics. What is more, the Nigerian political parties do not perform the aforementioned functions today. Virtually all the existing political parties are not well organized for them to be a catalyst for democratic sustenance and consolidation. They also do not compete over the issues they will pursue if elected into public office. Parties have failed to offer policy alternatives as expected of them. Hence, elections are not fought mostly on issues. Additionally, as reflected in successive general elections, the result of elections does not mostly reflect what people prefer going by the spontaneous reactions to the much-contested results. To be sure, parties fail to have elected officials bound by their campaign pledges. Therefore, there remains a wide gap between what is promised and what actually is delivered (Manafu I998, 2).

Whereas, according to the majoritarian model of democracy, parties are essential to making the government responsive to public opinion. Thus, four clearly identified principles of responsible party government postulated by Jerry Goldman et al. (Janda, Berry and Goldman I992), defines the ideal roles of parties in a democracy. These include:

- parties should present clear and coherent programmes;

- voters should choose candidates according to the party programmes;

- the winning party should carry out its programmes once in office;

- voters should hold the governing party responsible at the election for executing its programme (Janda, Berry and Goldman I992, 294). 
In line with these principles of responsible party government, political parties are expected to observe the following basic functions:

- Nominate candidates. This is a crucial function, so as to avoid a situation whereby the electorate will be faced with a bewildering array of self-nominated candidates.

- Structure the voters' choice. Political parties held democratic government by allowing the voters to have choices based on candidates' proposals or their party manifestos.

- Coordinate the actions of government officials. The leaders of the legislative and executive arms of government are not expected to be in agreement all the time. Political parties offer a platform for bridging the gaps, ensure functional separation of power and produce coordinated parties that will better the lot of the citizens (Janda, Berry and Goldman I992, 294).

It is in view of the afore-stated malady of political parties in the current democratic dispensation that now necessitated the need to evaluate their formation, development and prospects in Nigeria's bid to attain sustainable and consolidated democracy. One major observable feature of party politics in Nigeria is the absence of ideological class. Hence, the tendency is for these parties to see themselves as a force competing in a multi-ethnic civil society. Indeed, we equally note that these parties have interpreted political competitions in terms of the survival of the ethnic entities in which case political parties may have institutional ethnic solidarity rather than national outlook. They almost replicate Larry Diamond's description of political parties and party systems up to the Second Republic thus "they tended to reflect ethnic and regional peculiarities too closely to provide a fresh crosscutting basis for political conflict" (Oyediran and Agbaje I99I, 20). Corroborating Larry Diamond, Anthony Akinola notes that the political parties of the First Republic were "severely limited in their capabilities to integrate the components of that great diversity of societies known as Nigeria" (Akinola 1989). Indeed, as claimed by Chudi Nwazurike, they [political parties] "barely passed the critical litmus test for competitive democracy — the willingness to play by the rules - in fairly and squarely seeking power across the nation through an intemperate electoral process" (Oyediran and Agbaje I99I). The report of the Political Bureau in its comment on Nigerian political parties of the time averred that: 
The Nigerian pattern has exhibited virtually the worst forms of an unstable democracy. Most parties were narrow based, tied to some great and unassailable leader who tended to stamp the organization not with any grand ideological vision but his personal biases. Besides, each was ethnically based, mass-mobilizing and confrontational in orientation (FRN I987, I24-I32).

All these problems and fears make Nigerian political parties far from being catalysts to national integration and democratic stability.

Furthermore, of the eight phenomena identified by Celestine Mongu (I999), as fuelling collective skepticism about Africa's (indeed Nigeria's) democratization project, the point on the weakness of the political parties stood in bold relief. A contemporary political party is expected to meet four criteria, which Nigerian parties are lacking:

(a) Continuity that is having a life span that extends beyond those of its founders.

(b) Nationwide organization that is to seek to appeal to a wide range of electorate across the country in order to be able to actualize its primary objective of capturing power through the ballot box or by people's consent.

(c) It must desire to exercise power. A political party should not exist just to play the same role of a pressure group.

(d) Lastly, it must make consistent effort to garner significant popular support (Mongu i999).

As noted earlier in this piece, one of the major banes of party politics is ideological fluidity by politicians, which makes many politicians behave like political bats changing party affiliations in response to the political fortune of their group. Oyeleye Oyediran (I99I), however, identifies two factors as being responsible for this:

(a) the first is the basis for political party formation; and

(b) the second is the caliber and behaviour of political leaders whether or not they hold elective office (Ayandiji 2004, 83-Io0).

No doubt, Oyediran's observation is valid even in the current dispensation, which has however necessitated reforms (Adejumo and Kehinde 2007). Thus, if Nigeria's nascent democracy will be consolidated eventually, the issue of internal democracy within all registered political parties must 
be taken seriously. INEC should ensure that, legally, all parties comply with that requirement before candidates are fielded for elections. Lack of internal democracy has always been subject to litigation after elections when candidates complain that they were marginalized during primaries. Party primaries should be taken seriously (Ojo 20I9). A party that lacks democratic credentials internally cannot be expected to run a democratic government if it eventually wins election. For 20I9 elections alone, according to INEC, there were as many as 809 pre-election petitions filed before the general elections; the reformed electoral body should provide clear procedures for party primary and consequences of violations (Egburonu 2020, I5).

\section{Influence of money on politics}

One other fundamental problem which is in dire need of reform is the twin cankerworm of debilitating influence of money and corruption in the electoral process, which has negatively impacted on the body politik. Presently, political financing is indeed corrupted. The corruption in virtually all political systems vis-à-vis electoral processes manifest in one of the following ways:

(a) Political contributions that contravene existing laws on political financing.

(b) The use for campaign or party objectives of money that a political office holder has received from a corrupt transaction.

(c) Unauthorized use of state resources for partisan political purposes.

(d) Acceptance of money in return for an unauthorized favour or the promise of a favour in the event of election to an office.

(e) Contributions from disreputable sources, and

(f) Spending money on banned purposes such as vote-buying. (Pinto-Duschinsky 2004, I-23).

Meanwhile, the penchant of politicians to strive to win elections, even at the party primary levels, at all cost for that matter, makes desperate contestations to engage in all sorts of malpractices including offering financial and material inducements to voters. Chief Olusegun Obasanjo, Nigeria's ex-president confirmed this when he averred that: 
With so much resources being deployed to capture elective offices, it is not difficult to see the correlation between politics and the potential for high level corruption. The greatest losers are the ordinary people, those voters whose faith and investment in the system are hijacked and subverted because money, not their will, is made the determining factor in elections. Can we not move from politics of money and materialism to politics of ideas, issues and development? (Obasanjo I992, I38).

Chief Obasanjo also bemoaned the cost of conducting elections in Nigeria thus:

Even more worrisome, however, is the total absence of any control on spending by candidates and parties towards elections. I have said that we prepare for elections as if we are going to war, and I can state without hesitation, drawing from my previous life, that the parties and candidates together spent during the last elections more than would have been needed to fight a successful war (Obasanjo I992, I38).

Nonetheless, in a bold attempt to reduce the problem of vote buying by candidates, the 2006 electoral act placed a ceiling on how much a candidate can spend in contesting an election, section 93 sub-sections 92 (7) clearly stipulated that the maximum election expenses to be incurred by a candidate at a presidential election shall be N500,000,000; Governorship election Nı00,000,000; Senatorial seat N20,000,000; while the seat for House of Representatives shall be Nio,000,000 respectively. In the case of State Assembly election, the maximum amount of election expenses to be incurred shall be $\mathrm{N}_{5}, 000,000$, same amount for the chairmanship of local governments and $\mathrm{N}_{500,000}$ for council election (Electoral Act 2006, A48).

Cashing-in on the poverty of the people, Nigerian politicians are well known for distributing foodstuffs and other consumable materials to voters shortly before the elections and sometimes on Election Day, contrary to the provisions of the extant electoral law (as amended) that prohibits such practice. Instances abound too, when candidates threw some money into the air during campaign rallies, making people scramble for it and getting injured in the process (Adejumo I995, I25-I45). No doubt one of the critical areas that require reform is the issue of money as regards party financing cum campaign expenses. This can better be enhanced not only by law but institutional mechanisms that can properly monitor compliance strictly with the law. The greatest obstacle here is the inability of INEC to monitor election expenses of 
parties and their candidates; more so in a developing system where records are not kept coupled with criminal secrecy by candidates.

\section{Strengthening the weak state}

As a corollary to the aforestated, a weak state cannot successfully administer a free and fair credible election. For election administration to attain governmental legitimacy after polls has always been a serious concern to electoral scholars (Elklit and Keynolds 2000, I-37). It is well known that most new states in Africa, Asia and Latin America are too weak for the assignment. Thus, state capacity is a major prerequisite to successful polls. State power is said to consist of the following five elements:

(i) monopoly of the coercive power of society, that is, control of instrument of coercion;

(ii) the right to improve tax and collect revenue;

(iii) the power of legal enactment, that is, power to make laws;

(iv) sovereignty over territory and society; and

(v) control of the institutions of the state or state apparatus, bureaucracy (Onyeoziri 2005, 3).

These five elements taken together constitute the basis of state power and they endow the state with the status of statehood. But nation states which qualify for the status of statehood may differ in their degree of stateness, some are strong states, others are weak. No doubt, Nigeria falls into the category of weak states. Like others in her category, Nigeria runs a system, one in which formal rules (laws, officially stated administrative rules and practices etc.) are applied copiously and in a lax manner rather than rigorously and consistently. It is one in which private advantage can be gained and private bargains struck concerning the enforcement or non-enforcement of the rules as when a businessman bribes a tax official, besides money, another inducement is kinship sentiment and another is the favour of superiors.

The consequential effect is that in some cases individuals may be more powerful than the state in which the rule of law is abused with impunity. Cases of such were too numerous to be mentioned during successive elections. Meanwhile, the state requires to be strengthened and justice dispensed on time without fear or favour. This should be done in a way that after any general election, aggrieved parties should be able to have access to the courts/election petition tribunals which should be able to adjudicate such 
cases before the inauguration of a new government; and also justice seen to be done vis-à-vis electoral offences.

In the same perspective, all security apparatus of the state must be given sufficient re-orientation in what their constitutional roles should be before, during and after elections. The experience with the last general election was not palatable, security agents were biased doing the biddings of the ruling party. The consequential effect of this was an unprecedented rate of electoral violence all over the country. Indeed, the tempo, and character of electoral violence, resulting from representational campaign, balloting and result conflicts, has been a terminal problem of Nigerian politics since the I950s (Albert 2007, I32). According to INEC sources, the violence led to 265 cases of electoral violence, recorded all over the country during the governorship and State House of Assembly elections on $14^{\text {th }}$ April 2007 elections alone. During the same period, I,093 persons were arrested, II civilians killed and 39 policemen also lost their lives ${ }^{6}$. Put differently; when one man's corps is another man's thug, the bastardized, ill-trained and poorly paid security agencies can never assist in the maintenance of law and order?. The reform agenda should carry the law enforcers along. It is by doing so that Nigerian state will be waxing stronger.

\section{The judiciary and credible elections}

The judiciary is a cardinal institution in our established democracy. This is not unconnected with the fact that the constitutional government must in part be a judicial government (Hague et al. I983, 279). As the third organ or branch of government, the constitution vests it inter alia with the

6 For the spate of electoral violence all over the country during the last general elections, see Sunday Tribune, Ibadan, I5 April, 2007. The Tribune chronicle recounted below is not cheering:

- $\quad$ 6r killed in Rivers, Lagos, Osun, Oyo, Borno, Abia, Edo

- Ballot boxes snatched, burnt

- PDP leader shot dead in Ekiti.

- 2 Police stations burnt in Port Harcourt

- $\quad$ I7 fake soldiers arrested in Ibadan, 3 in Enugu, I,500 thugs arrested

- $\quad$ Bisi Akande quizzed over possession of gun

- This election is horrible - Senate President

- We didn't anticipate this - INEC Chairman

- What a state of anomie?

7 For a full detail of electoral violence in 20II general elections see, Emmanuel O. Ojo 'Bunker' Democracy and the Challenges of Sustaining Democratic Values in Nigeria - An Appraisal of the 20 II General Elections, in Journal African Elections, Vol. I5 No. I (June). 2016, pp. 93-гі2. 
powers to interpret and apply all laws in the country in relation to both criminal and civil matters and disputes between individuals and groups, between individuals and political authorities, as well as, between political authorities in a parallel relationship or in a vertical relationship, such as between one state and the federal government in a federal system (Awa I996, 8). Thus, it is the guardian of the rule of law and the upholder of justice, fair play and equity. This is the reason why in Nigerian constitutions it enjoys the greatest measure of independence from both the executive and legislative arms of government, except during military interregnum (Ojo 2000, I).

Meanwhile, beyond mere theoretical postulations, the Nigerian judiciary has manifested a number of shortcomings which eminently qualifies it for reform and total overhauling. In a relatively complex society, like Nigeria people are appointed even into the Supreme Court not on merit but on such nebulous grounds of religious and ethnic balance, federal character, seniority, zonal representation and old school ties (Osuntokun 2008). The effect of this is divided loyalty and inability to uphold the solemn principle and ethics of judicial independence. This is one of the constraints of the judiciary in Nigeria.

Secondly, as long as there is no fiscal or financial independence of the judiciary, it will continue to be subject to the control of the purse. This is not ideal for a judiciary that is worth its salt. We have seen in recent times in Nigeria especially after the poorly conducted and violently rigged and manipulated elections of 2007 that the judiciary is perhaps the only institution standing between justifiable resistance to electoral manipulation and anarchy (Osuntokun 2008). The 2006 Electoral Act makes the judiciary the final arbiter of electoral disputes. But, where it is taking the judiciary too long a time to resolve electoral cases before them thereby permitting the wrong people to occupy positions of power for years unduly before respite comes the way of petitioners are uncalled for; compounded with this are several allegations of corruption both against the bar and the bench. Until these issues are addressed, a free and fair election may not be easily attainable in Nigeria.

\section{Conclusion}

In the final analysis, there should be a dispute resolution mechanism during and after elections (Mukele 2007, 4). This is what a restructured electoral system should look like. Be that as it may, it needs to be emphasized that, whatever reform or restructuring put in place, Nigerians need to be 
re-oriented - both the followers and the led - on what it takes to have a credible election. The snag is that Nigerians are not democrats thereby the possibility of having democracy becomes a mirage. It is only when re-orientation is done, which takes time that a kind of political culture congruent to democratic sustenance can ever evolve. Above all, the present level of excruciating poverty is uncalled for. The poor will be receptive to reform, while the rich find them useful in perpetuating electoral atrocities. The envisaged restructuring must not lose sight of the parlous state of the economy. This is where civil society organizations need to be reanimated and galvanized for it to be able to discharge its duties well. No doubt, the dimensions of electoral reform discussed in this paper are far from being exhaustive, but indeed salient towards the attainment of a better and improved system, more so, to call for a perfect human system is to anticipate Eldorado and utopia which is never the goal of reform, but rather improvement on the existing system.

A holistic electoral reform agenda would no doubt bring about an INEC that would be autonomous and shielded from political manipulation especially from the political party in power. There should usually be a clause in the law stating that in the exercise of its functions, it shall not be subject to the dictate of any other person or authority. The office of the chairman and commissioners shall be so protected that it would not be easy or possible to sack them at the whims and caprices of the executive. Not only that the legal framework shall be sufficiently glaring on the electoral body for it to be able to take quick decisions. Also, such a commission shall have powers to hire and fire personnel, without being restricted to seconded officers and ad hoc staffer that cannot be effectively disciplined.

\section{References}

Adejumo, S. and Kehinde, M. 2007. "Building Democracy without Democrats: Political Parties and Threats of Democratic Reversal in Nigeria", Journal of African Elections, Special Issue, Nigeria's 2007 General Elections, Vol. 6, No. 2 (Oct.).

Adejumo, S. I995. "The Two Political Parties and the Electoral Process in Nigeria: I989-I993". In The State and Democracy in Africa, edited by Georges Nzongla-Ntalaja and M.C. Lee. Harare AAPS Books.

. 2007. When Votes Do Not Count: The 2007 General Elections in Nigeria. A publication of the Nordic Africa Institute, Uppsala, Sweden. 
Adekanye, J.B. I990. "Election in Nigeria: Problems and Strategies", Journal of Electoral and Political Behaviour (Nigeria), Vol. I No. I.

Akinola, A. 1989. "A Critique of Nigeria's Two Party System", The Journal of Modern African Studies, vol. 27, No. I (March).

Anifowose, R. 2003. "Theoretical Perspectives on Elections". In 2003 General Elections and Democratic Consolidation in Nigeria, by Remi Anifowose and Tunde Babawale. A Publication of Friedrich Elbert Stiffing, Franked Publishers, Lagos.

Awa, E. 1996. "Democracy in Nigeria: A Political Scientist's View". In Governance and Development in Nigeria - Essays in Honour of Prof. B.J. Dudley, edited by Oyediran, O. A Publication of Oyediran Consult International, Ibadan.

Ayandiji, D.A. 2004. "Party and Electoral Politics". In Nigeria's Struggle for Democracy and Good Governance (A festchrift for Oyeleye Oyediran), edited by Agbaje, A.A.B., Larry Diamond and Ebere Onwudiwe. Ibadan university Press, Ibadan.

Egburonu, Sam. 2020. "Challenges facing INEC's e-voting vision", The Nation, Lagos, (Sunday March I5).

Elklit, J. and Reynolds, A. 2000. "The Impact of Election Administration in the Legitimacy of Emerging Democracies: A New Research Agenda", being a paper prepared for delivery at the 2000 Annual Meeting of the American Political Science Association

Federal Republic of Nigeria. I987. Report of the Political Bureau, Lagos. .2006. Electoral Act 2006, An official Gazette printed and published by the Federal Government Printers, Lagos, Nigeria.

Femi, O. 2007. "Go Robert Mugabe, Go", The Nation, Lagos, September 8.

Hague, R. et al. I983. Comparative Government and Politics, $3^{\text {rd }}$ edition, Macmillan, London.

IFES-Nigeria. 2007. A Nigerian Perspective in the 2007 Presidential and Parliamentary Elections: Results from Pre- and Post-Election Surveys, Abuja, August (Monograph).

Ijim-Agbo, U. 2007. "The Independent National Electoral Commission as an (Im)Partial Umpire in the Conduct of the 2007 Elections", Journal of African Elections. (Spcial Issue), Nigeria's 2007 General Elections, Vol. 6, No. 2 (Oct.).

International IDEA. 2000. Democracy in Nigeria: Continuing Dialogue(s) for Nation Building, Stockholm, Sweden. 
Janda, K., Berry, J.M., and Goldman, J. I992. The Challenge of Democracy:, Government in America, $3^{\text {rd }}$ Edition, Houghton Mifflin Company, USA.

Kolawole, D. 2007. "Democracy, Elections, Majoritarianism and the Nigerian Factor", The Nation, Lagos, (July I3).

Manafu, A. I998. "Comparing the U.S. and European Political Parties", Indian Journal of Politics, vol. xxxii, Nos. I \& 2.

Molomo, M. G. 2006. "Democracy and Botswana's Electoral System", Journal of African Elections (Special Issue), in Elections and Democracy in Botswana, Vol. 5, No. 2 (December).

Mongu, C. I999. "Eight Problems with African Politics" in Larry Diamond and Mark Plattner (eds), Democratization in Africa, London, The John Hopkins University Press.

Obasanjo, O. and Mabogunje, A. I992. Elements of Democracy, ALF Publications, Abeokuta, Nigeria.

Ogunsanwo, A. 2003. "Keynote Address". In 2003 General Elections and Democratic Consolidation in Nigeria, edited by Remi Anifowose and Tunde Babawale. A Publication of Friedrich Elbert Stiffing, Franked Publishers, Lagos.

Ojo, Emmanuel O. 2000. "The Judiciary, Phenomenon of Corruption and Sustenance of democratic Values in Nigeria." A Prognosis, being a paper presented to the Faculty of Business and Social Sciences Seminar series for 1998/1999 Academic Session, University of Ilorin, (February).

. 2019. "Party Primaries and Candidate Selection in Nigeria, 19992009" POLAC Historical Review, Vol. 3 No. I (July-Dec).

. 2003. "Governance and Legitimacy Crisis in Nigeria", Research for Development, Vol. ig Nos I \& 2 (December).

. 2012. "Fraud-Free Election as the Bastion of Democracy and Good Governance". Fraud-Free Election, being proceedings of a 2-day workshop on preventions of Electoral Fraud in 2011 General Elections in Nigeria, edited by Mudasiru Salami \& Akanni Waliyulah Oladotun, I6-I7 March, 20II, held at Mustapha Akanbi Foundation, Ilorin, Kwara State, Nigeria.

. 2003. "The Mass Media and the Challenges of Sustainable Democratic Values in Nigeria: Possibilities and Limitations", Media Culture and Society, Sage Publications, London, Vol. 25. 
. 2006. "Vote Buying in Nigeria", Money, Politics and Corruption in Nigeria, a Publication of IFES - Nigeria, Abuja (May).

. 2007a. "Fourth Estate of the Realm or Wreck: Media, Government and the Nigerian State", Babcock Journal of Mass Communication, Vol. I, No. 2 (Jan.).

. 2007b. "Nigeria's 2007 General Elections and Succession Crisis: Implications for the Nascent Democracy", Journal of African Elections, Vol. 6, No. 2 (Oct.).

. 2007c. "Elections: An Exploration of Theoretical Postulations", Journal of African Elections. (Special Issue), Nigeria's 2007 General Elections, Vol. 6, No.2 (Oct.).

Olurode, L. I990. A Political Economy of Nigeria's 1983 Elections, John West Publications Limited, Lagos.

Olurode, L. and Anifowose, R. (eds.). 2004. Issues in Nigeria's 1999 general Elections. John West Publishers Ltd and Rebonik Publications Ltd., Lagos.

Onwudiwe, E. \& Berwind-Dart, C.. 20Iо. "Breaking the Cycle of Electoral Violence in Nigeria", US Institute of Peace (Special Report 63), US Embassy, Lagos.

Onyeoziri, F. 2005. "Federalism and State Capacity in Nigeria", Ibadan Journal of the Social Sciences, Vol. 3, No. 2 (September).

Osuntokun, J. 2008. "Judiciary and the Sustenance of Democracy: The Nation, Lagos (serialized between March 20-April 3).

Oyeleye, O. and A.A.B. Agbaje. I991. "Two Partyism and Democratic Transition in Nigeria", Journal of Modern African Studies, Vol. 29, No. 2.

People. 2007. "The Maurice Iwu Story" The Truth about 2007 Polls, Great and Gamaliel Alliance Limited, Garki, Abuja, (July).

Pham, P.J. 2007. "Nigeria Crisis of Legitimacy", The Guardian, (April 29), Lagos.

Pinto-Duschinsky, M. 2004. "Financing Politics: A Global View" Political finance and Democracy in Nigeria, Centre for Law and Social Action (CLASA), Lagos.

Samuel, S. T., 20I6. "Political Thuggery and Election in Nigeria and the Law". http://nials-nigeria.org/journals/shakynla\%2oGTersoo\%20 samuel.pdf. Accessed Mar. 24, 2016.

Tinubu, B.A. 2007. "Thoughts on the Electoral Reform Panel", Sunday Tribune, (Sept. 9), Ibadan. 
US Department of State. 200I. Reports on Nigeria in 20I0, Lagos, Consulate General of the US, Nigeria, Lagos.

Vale, P. 2005. "South Africa and Zimbabwe: Democracy in the Littoral Zone", Journal of African Elections (Special issue on Zimbabwe's 2005 General Election), Vol. 4, No. 2 (Oct).

\begin{abstract}
No doubt, successive general elections in Nigeria fall far below internationally acclaimed minimum standard for a free and fair election. Whereas, democracy which is the desire of Nigerians will survive only if its basic and elementary rules - free and fair election for citizens - in terms of one-man-one-vote for the citizenry to exercise their choice are observed - unfortunately, "a number of elections did not meet even the barest minimum requirement in a failed state". It is against this background that this paper now attempts a prognosis of the dimensions of electoral reforms and the likely challenges so that the beleaguered nascent democracy can resist the possibility of reversal to autocracy. To achieve this aim, the paper has been organized into a number of sections. With an introductory overview, which dwells on the imperatives of a free and fair election in Nigeria, the paper proceeds to brief theoretical postulations that bother on the nexus between democracy and credible elections. The paper however proceeds to the dimensions of restructuring the electoral institutions to be able to guarantee free and fair credible elections. Few of the areas of concentration for restructuring includes: a review of the electoral acts, rejig of INEC, political parties and internal democracy, the debilitating influence of money in politics most especially vote-buying, strengthening the weak state and the role of the judiciary in credible elections amongst others. The paper however infers that even if all restructuring dimensions are undertaken, the state must be strengthened from its present extremely weak status cum adoption of IT while Nigerians need to be given re-orientation so that they can imbibe a congruent political culture vis-à-vis democracy.
\end{abstract}

\title{
KEYWORDS
}

Democracy. Election. Reform. Restructuring. Consolidation.

Received on November 23, 2020 Accepted on January 14, 2021 